University of Nebraska - Lincoln

DigitalCommons@University of Nebraska - Lincoln

Faculty Publications: Department of Teaching, Department of Teaching, Learning and Teacher Learning and Teacher Education

Education

8-2018

\title{
Testing and Ideology: Policy Debates about Literacy Assessments for Colorado's Bilingual Students
}

Luis E. Poza

San José State University, luis.poza@ucdenver.edu

Kara Mitchell Viesca

University of Nebraska-Lincoln, kara.viesca@unl.edu

Follow this and additional works at: https://digitalcommons.unl.edu/teachlearnfacpub

Part of the Bilingual, Multilingual, and Multicultural Education Commons, Curriculum and Instruction Commons, and the Teacher Education and Professional Development Commons

Poza, Luis E. and Viesca, Kara Mitchell, "Testing and Ideology: Policy Debates about Literacy Assessments for Colorado's Bilingual Students" (2018). Faculty Publications: Department of Teaching, Learning and Teacher Education. 341.

https://digitalcommons.unl.edu/teachlearnfacpub/341

This Article is brought to you for free and open access by the Department of Teaching, Learning and Teacher Education at DigitalCommons@University of Nebraska - Lincoln. It has been accepted for inclusion in Faculty Publications: Department of Teaching, Learning and Teacher Education by an authorized administrator of DigitalCommons@University of Nebraska - Lincoln. 


\title{
Testing and ideology: Policy debates about literacy assessments for Colorado's bilingual students
}

\author{
Luis E. Poza ${ }^{1}$ and Kara M. Viesca ${ }^{2}$ \\ 1 Connie L. Lurie College of Education, San José State University, San José, CA \\ 2 College of Education and Human Sciences, University of Nebraska-Lincoln, Lincoln, NE \\ Corresponding author - Luis E. Poza luis.poza@sjsu.edu Connie L. Lurie College of Education, \\ San José State University, 1 Washington Square, San José, CA 95112, USA \\ ORCID - Luis E. Poza http://orcid.org/oooo-0oo2-6775-8719
}

\begin{abstract}
The Colorado Reading to Ensure Academic Development Act requires grade-level attainment in literacy in English for students in grades K-3. Its practical outcome, however, has been to pressure schools with bilingual programs to shift their instructional language allocations towards more English in the early grades. Proposed rule revisions debated by the state Board of Education sought to facilitate testing in students' language of instruction for those in bilingual programs. Analysis of written and verbal opposition to the proposed rule revisions demonstrates the persistence of insidious ethnoculturalist discourses opposing bilingual education as well as the cooptation of liberal multiculturalist discourses that, while framing bilingualism as an asset, argue that it is underdeveloped in bilingual programs that do not include English instruction from the outset. Given that bilingual instruction has demonstrated time and again that it benefits students acquiring English in schools, such new discursive turns pose a threat that must be recognized to fend off further legislative and regulatory attempts against bilingual education.
\end{abstract}

Keywords: Language ideologies, bilingual education, language policy and planning (LPP)

Published in Journal of Education Policy (2018)

https://doi.org/10.1080/02680939.2018.1511831

Copyright (c) 2018 Informa UK Limited, trading as Taylor \& Francis Group. Used by permission. Submitted 12 December 2016; accepted 10 August 2018; published 24 August 2018. 


\section{Introduction}

In the United States, Spanish and its speakers have been largely seen as a social problem (Ruiz 1984), characterized as a burden to national unity, the economy, and education systems (Del Valle 2003; Galindo 1997; García 2009a, 2009b, 2014; Santa Ana 2002, 2004; Wiley 2000, 2013, 2014). All too often, the proposed remedy to this assumed problem has been to try to assimilate speakers of other languages into an English monolingual paradigm. Evidence of this assimilationist trend can be found in the hostility encountered by multilinguals for using languages other than English or non-standardized varieties of English in what Hill calls the 'white public space' (Hill 1995, 1998; Urciuoli 1996). This antagonism reflects ideologies that interweave beliefs about the nation with concepts of race and language, such that multilinguals, particularly US Latinxs, are racialized and framed as a social burden (Santa Ana 2002; García 2009b). Moreover, this racialized and nativist monolingual ideology also manifests in less direct ways, including reduced support for languages other than English in schools, particularly in the form of bilingual education.

In this work, we consider a policy debate in the state of Colorado. In 2012, the Colorado legislature passed the Colorado Reading to Ensure Academic Development Act (READ Act 2012). The READ Act's emphasis on grade-level attainment in literacy for students in grades K-3 was initially interpreted as literacy in English and had the practical outcome of pressuring schools with bilingual programs to shift their instructional language allocations towards more English in the early grades. Given these unintended consequences, and a statement issued by the State Attorney General clarifying that literacy skills did not have to be demonstrated or achieved only in English according to the law, revisions were proposed for READ Act regulations facilitating the use of Spanish literacy assessments for students in bilingual programs per districts' judgment. Opposition to these revisions in submitted written comments and through the questions and discussion that took place before the Board of Education demonstrates an important evolution in the discourses undermining bilingual education. 
Our inquiry focuses on the particular hearing of the Colorado Board of Education in which these rule revisions were first discussed and put to a vote. The research questions at hand are the following,

(1) What discourses comprise opposition and support for Spanish literacy assessment during this particular hearing?

(2) How do the discourses opposing the rule revisions align with or differ from prior rhetorical opposition to bilingualism and bilingual education in US policy debates?

This study focuses on the single Board of Education meeting at which the rule revisions under consideration were discussed for two reasons (for more information about the READ Act, main actors, and a timeline of key events, see CDE, 2017; Viesca and Poza, forthcoming). First, the hearing marks the first notable instance in which bilingualism and bilingual education were a central topic of discussion rather than an ancillary concern to broader implementation of the law. Second, it signals the emergence of new discourses that, under the cover of neoliberal perspectives about bilingualism (Flores 2013b; Petrovic 2005), undermine bilingual education by challenging established principles of effective bilingual programs. The argument we offer is that by professing to support students' bilingualism by mandating testing in English before such testing provides valid evidence of their abilities, certain members of the Board of Education were, intentionally, undermining bilingual education knowing that such testing had thus far pushed programs to move from maintenance to transitional models or to abandon bilingual education altogether. Placing the READ Act in this context, our subsequent review of the literature, which also offers our conceptual framework, explains how dominant racial and linguistic ideologies in the US pervade educational policy regarding Latinx emergent bilinguals, and points to the ways that discourse in general - and specific discourses about bilingual education in particular - can constrain learning opportunities for this group. Our conceptual framework joins three strands of literature: language policy and planning, LatCrit, and, finally, language ideologies and their discursive enactments. 


\section{Review of the literature}

\section{Language policy and planning}

We situate our work in the field of language policy and planning, which considers the ideological dimensions that promote or suppress particular language practices and the people who use them, as well as the mechanisms, both explicit and implicit, by which this promotion or suppression occurs. Within this field there has been ample consideration of the subjugation of languages other than English in the United States (for comprehensive reviews, see Del Valle 2003; and Wiley 2013, 2014), and particularly examination of the exceptional and marginalized position of Spanish and Spanish-users (e.g.: García 2014; Macías 2014). With respect specifically to bilingual education, extensive work has also chronicled the ebbs and flows of support for bilingual programming in the United States, noting early acceptance prior to World War I, a brief resurgence in the 1960s and 1970s, and the current restrictive climate (García 2014; Menken and Solorza 2014; Nieto 2009; Ovando 2003; San Miguel 2004; Wiley 2007, 2014). Moreover, these works show how policies need not offer explicit prohibition in order to suppress bilingual education.

Shohamy (2006), in her examination of the myriad legislative, regulatory, and interactional means by which societies' language use is shaped, describes mechanisms including language testing as the linkage between language ideologies and the practical linguistic realities they wish to foster. Regarding language tests, Shohamy states, 'it acts as a most powerful mechanism for affecting and manipulating language behaviors and the use of students, teachers, parents, and society as a whole,' (2006, 93). Shohamy adds that tests play decisive roles in placing languages in prestige/status hierarchies, perpetuating regimes of language standardization, and stifling linguistic diversity (95). Providing a concrete example of this phenomenon, Menken (2006, 2008) and Menken and Solorza (2014) study the prevalence of bilingual programming and the curriculum within bilingual schools in New York following passage of the No Child Left Behind Act in 2001, which stressed English language acquisition through sheltered English immersion and removed the word bilingual from federal education documentation (Nieto 2009). The authors report that while NCLB 
contained no explicit prohibition of bilingual education, its emphasis on English language development for emerging bilingual students (not only Latinxs) and its accountability mechanisms tied to high stakes tests of academic content in English had a chilling effect on bilingual instruction. The READ Act rules in dispute in the present analysis similarly required testing in English even for students receiving their literacy instruction in Spanish, and would presumably have similar effects on districts' willingness to educate their students bilingually.

Prior policy debates in the education of emergent bilinguals

The debate over proposed rule revisions in the READ Act brought together various fraught discussions of educational policy and practice. First and foremost, it raised the question of how best to assess students developing English. Beginning with the May 25th Memorandum, a note to the field issued by the Department of Health, Education and Welfare (DHEW) in 1970 regarding civil rights protections for students learning English under Title VI of the Civil Rights Act that precludes discrimination on the basis of national origin (among other traits), protections were put in place to prevent the tracking or penalizing of students 'on the basis of criteria which essentially measure or evaluate English language skills' (DHEW 1970). Since then, notable effort has been expended to develop valid and reliable assessments and to critique the current practice of relying on high-stakes tests in English for determinations of academic proficiency (Abedi 2002; Abedi and Gándara 2006; Durán 2008; Solano-Flores 2008; Solórzano 2008).

The rule revisions also evoked the debate over the role of home language instruction for bilingual learners. As early as 1968, the US government recognized the value of such an approach in the Bilingual Education Act (Title VII of the reauthorized Elementary and Secondary Education Act [ESEA], first issued in 1964), which stated 'quality bilingual education programs enable children and youth to learn English and meet high academic standards including proficiency in more than one language' (Bilingual Education Act 1968, 2). The Supreme Court's opinion in Lau v. Nichols (1974), the Equal Educational Opportunities Act of 1974, and the 1974 reauthorization of ESEA all affirmed emergent bilingual students' rights to access curriculum and broadened possibilities for bilingual programming. Moreover, the Lau 
Remedies issued in 1975 by the Office of Civil Rights instructing districts how to comply with Lau clearly and forcefully voiced support for home language instruction. Nevertheless, in spite of this rash of decisions and policies supporting bilingual education and mounting research to confirm its benefits, subsequent reauthorizations of the ESEA in the 1980s lacked sufficient allocations for bilingual education. Despite a brief ascendance under the Clinton administration that championed dual language programs (bilingual models comprised of half linguistic minority students and half dominant group students) and signed a reauthorization of ESEA in 1994 that restored funding for bilingual programming, bilingual education faced decreasing support culminating in state-level initiatives banning the practice in California, Arizona, and Massachusetts, and the aforementioned No Child Left Behind Act (Nieto 2009).

\section{LatCrit}

This work operates within the field of LatCrit, an extension of Critical Race Theory 'beyond the limitations of the black/white paradigm to incorporate a richer, more contextualized analysis of the cultural, political, and economic dimensions of white supremacy, particularly as it impacts Latinas/os,' (Iglesias 1996, 178). Similar to Critical Race Theory, LatCrit calls attention to hegemonic racial ordering that covertly or expressly marginalizes communities of color, particularly in law and legal institutions. Valdés (1997a) further offers that LatCrit, in his conceptualization of the field, has a fourfold mission, consisting of: 1) the production of knowledge through the study and critique of social and legal circumstances hamstringing Latinx communities; 2) the pursuit of transformation of social and material circumstances for marginalized communities; 3) paying attention to diversities and intersectionalities within Latinx communities and, moreover, linking struggles for Latinx empowerment with aims of social justice and other communities' struggles broadly; and 4) creating and nurturing egalitarian intellectual, political, and social relationships among diverse scholars with shared dispositions in their work on legal theory, (1997, 7-8).

Thus, this work considers the READ Act rulemaking negotiations against a backdrop of educational and public policy that has served to 
disproportionately impact emergent bilingual Latinx students in US schools. Latinxs have been discriminated against and marginalized since the nation's inception, with their language (whether Spanish or non-standardized English varieties) often serving as a justification for discrimination when ethnicity could not. For instance, while German was allowed in schools and broad social use in Ohio and Pennsylvania with comparatively less opposition, the prevalence of Spanish was subject to restrictions in California after its admittance to the union in 1850 and was a principal reason for the denial of New Mexico's early bids for statehood in the late 18th and early 19th Centuries (Del Valle 2003). Moreover, even when significant victories have been achieved, we can observe pernicious deficit framings of Latinx and/ or emergent bilingual students. The most notable example of this is in the case of Mendez v. Westminster (161 F.2d, 774, U.S. App, 1947), decided by the 9th Circuit Court of Appeals, which prohibited segregation of Mexican-descended students from schools in various California districts. In its decision, the Court stated,

The evidence clearly shows that Spanish-speaking children are retarded in learning English by the lack of exposure to its use because of segregation, and that commingling of the entire student body instills and develops a common cultural attitude among the children which is imperative for the perpetuation of American institutions and ideals, (64 F. Supp, 544, 549).

While this case is, rightfully, heralded as a major civil rights victory in terms of granting access, the rhetoric of the opinion clearly implies concern for the ability of Spanish speaking students to assimilate to the dominant culture with its monolingual trappings and a conflation of ethnicity (since the Mendez girls were excluded from school on the basis of surname and skin color) with linguistic ability.

Likewise, the aforementioned Bilingual Education Act, while providing allowances and resources for bilingual programming, still framed English proficiency and incorporation to dominant ways of being as the ultimate goal of such programming (Sung 2017). Similar reasoning underpinned the opinions in Plyler v. Doe (457 U.S. 202, 1982), which prohibited the exclusion of undocumented students from 
public schools, and Lau v. Nichols (414 U.S. 56, 1974), the pivotal decision ensuring access to curriculum for students in early stages of English language development. In both opinions, the utilitarian and assimilative function of school to instill cultural and linguistic uniformity is offered as the basis for providing access for undocumented students and emergent bilinguals, respectively, two groups in which Latinxs feature prominently.

Finally, and of central relevance to the context of Colorado, the mobilization that defeated the 2002 attempted ban on bilingual education in the state, Amendment 31, demonstrated both deficit framings of Latinx emergent bilingual students and the role of what Bell (1980) calls 'interest convergence,' wherein benefits for subjugated groups also benefit the dominant group, precipitating the provision of said benefits. As with the prior cases mentioned, this campaign also provides much to celebrate. Unlike California, Arizona, and Massachusetts, Colorado was able to ward off the odious restrictions. Moreover, the No-on-31 campaign was comprised by an impressive coalition of educators, researchers, litigators, parents, and advocacy organizations that fought the amendment through multiple channels and with remarkable discipline in the face of bilious attacks and accusations (Escamilla et al. 2003).

Nevertheless, the campaign also had to reverse substantial initial popular support for the amendment, and ultimately decided, in coalition with leaders from the Latino community, on emphasizing messages of government overreach, punitive measures in the bill against teachers, and likely cost increases instead of overt anti-racist or civil rights discourses even in the face of personal attacks from proponents of the ban (Escamilla et al. 2003). Moreover, in the waning days of the campaign, the parent of a child in a dual language school made a $\$ 3$ million contribution that was spent on a television advertisement that warned of Latinx children stifling the learning of White, English monolinguals if the two were forced into the same classrooms by the elimination of bilingual programs (Flores 2015). The advertisement, a lamentable and possibly unnecessary measure given how polls had already shown support shifting to opposition of the measure after months of sustained organizing (Escamilla et al. 2003), has unfortunately come to overshadow the discipline, hard work, and broad coalition building that truly turned the tide against Amendment 31. 
This transgression was committed without the knowledge of many of the lead organizers, per personal correspondence from 2017 with Dr. Sheila Shannon, one of the campaign leaders. While it should not distract from how pragmatism and strategizing were generally necessary to prevent the ban from passing, it is the culminating example of how mainstream support for preserving bilingual education was tied to the interests of White, English-monolingual dominant interests.

Our intent is not to be cynical about these victories. They comprise jurisprudence and educational policy that has afforded significant improvement in the opportunity landscape for Latinx, immigrant, and emergent bilingual students (and we note that while there is overlap between these groups they are not interchangeable labels). However, by calling attention to these deficit framings and to the assimilationist impulses behind them, perhaps we can see why anti-immigrant and anti-bilingual rhetoric endures. Thus, a LatCrit framework affords us an appreciation for how policies and rules that overtly limit or implicitly discourage bilingual instruction-well established as the most effective program of instruction for bilingual learners (Rolstad, Mahoney, and Glass 2005; Umansky and Reardon 2014; Valentino and Reardon 2015) - are part of a larger regime of marginalization. The connections to this broader plane, which includes nativist and racist ideologies about Latinx individuals and communities, are informed by the second strand of our theoretical framework, that of discourse and language ideologies.

\section{Language ideologies and discourse}

As we explain in greater detail in the Methods section, this work relies on a conceptualization of discourse that emphasizes language as a social practice inevitably interwoven with racial, political, and other cultural formation projects (Rogers et al. 2005). With respect to the subject at hand, this implies attention to the ways in which the normativity of White, monolingual ways of speaking and developing literacy skills are reified in discourses observed during Board Members' discussion as well as public written comment about curriculum and educational accountability systems for emergent bilingual Latinx students in bilingual programs. These discourses reflect language ideologies that intersect with ideologies about race and nationality, positioning 
the language practices of these students on the periphery and subjecting them to scrutiny and repression.

Language ideologies underlie many of the pernicious discourse patterns opposing bilingual education as a valuable instructional model. Kroskrity (2004) defines language ideologies as a 'ubiquitous set of diverse beliefs, however implicit or explicit they may be, used by speakers of all types as models for constructing linguistic evaluations and engaging in communicative activity. They are beliefs about the superiority/inferiority of specific languages,' (497). Similarly, Irvine (1989) explains the term as, 'the cultural (or subcultural) system of ideas about social and linguistic relationships, together with their loading of moral and political interests,' (255). Thusly, we understand the term to encompass popular notions manifest in speech and deed that place different language practices in hierarchy. Of course, for such beliefs to be of consequence and have this stratifying effect, they must materialize into the provision or abridgement of opportunities to individuals or groups on the basis of their language practices. The importance of considering discourses in analysis of policy debates is that these can normalize and reify these particular ideologies and inculcate them into a society's laws and norms (Viesca 2013). Herein we review two prevalent discourses with respect to the bilingualism of US Latinxs and bilingual education in the United States.

\section{Ethnoculturalist discourses}

Ethnoculturalist discourses reflect a conceptualization of US identity as White, Christian, English-speaking, and European-descended (Schildkraut 2003; Smith 1997). In this case, these (often intersecting) anti-Spanish and anti-Latinx discourses position Spanish as foreign and incompatible with this identity, and have been widely documented. Hill (1995), for instance, describes the use of Mock or Junk Spanish among Whites in the US as a means by which stereotypes of Latinxs as lazy, ignorant, criminal, and lascivious are indexically perpetuated. Hill argues that while Whites can use Spanish to interject levity and convey their own joviality, 'It is fairly easy analytically to show that Junk Spanish is driven by a racist semiotic, and that it functions to reproduce negative views of Spanish speaking people' (Hill 1995, 208). Urciuoli (1996) and Zentella (1997), in linguistic 
ethnographies of Puerto Rican communities in New York, comment on the feelings of hypersurveillance and insecurity that women encountered in their use of English outside their communities, and on the hostility with which their Spanish could be received. Focusing more on Latinxs as an ethnic group rather than a linguistic community, Benjamin (2009) and Santa Ana (2002) analyze references to Latinxs in public forums and mass media, respectively, noting the prevalence of metaphors such as a time bomb, a flood, a tidal wave, and an invading army. These overlapping nativist and anti-Spanish sentiments are perhaps best depicted in the words of Huntington (2004), who wrote,

The central elements of that culture can be defined in a variety of ways but include the Christian religion, Protestant values and moralism, a work ethic, the English language, British traditions of law, justice, and the limits of government power, and a legacy of European art, literature, and music. (40)

This link between English and US national identity is further affirmed by the work of Schildkraut (2003), who conducted focus groups in which various official English policy measures were debated. She identifies three conceptions of US identity, including ethnoculturalism, 'the belief that Americans are white English-speaking Protestants of northern European ancestry,' (474). She notes that those holding this particular conceptualization tightly linked English to national identity, while also strongly supporting official English policies and expressing some anti-immigrant sentiment. It is worth repeating, of course, that immigrant status, English proficiency, and Latinx ethnicity are three separate categories that only sometimes overlap. Nevertheless, as Flores and Rosa (2015) remind us, however, they are all too often linked in the imagination of a 'white listening subject' (151) adherent to ideologies linking nationhood to birthplace, language, and phenotype all at once.

These negative dispositions about Latinxs and Spanish permeate discourses specifically about bilingual education for Latinx emergent bilinguals as well. Despite its demonstrated benefits for students acquiring the societally dominant language in schools (see Rolstad, Mahoney, and Glass 2005; Valentino and Reardon 2015), bilingual 
education has been framed by opponents as a means of resisting assimilation into the dominant milieu or as a hindrance to academic achievement and development of English language proficiency. Johnson (2005), for example, analyzed the metaphors deployed in various media outlets' coverage of Arizona's Proposition 203, which severely restricted bilingual education in the state in the year 2000. This work notes that English was again positioned as integral to achievement of the 'American dream' while bilingual students were repeatedly framed as victims failed by bilingual education. García (2014), reviewing the history of educating emergent bilingual Latinx students, offers that contemporary opponents of bilingual education insidiously framed Spanish as a foreign and invasive language, disregarding its historical presence in vast swaths of the nation, and framed it as a pivotal factor in students' poverty and academic underachievement. Wiley (2000, 2014) notes this same erasure of the nation's historically multilingual character and assertion of ideologies promoting English monolingualism and immigrants' linguistic assimilation to justify certain policy prescriptions, including restrictions on bilingual education. Gándara and Contreras (2009), through analyses of social policies that create and reinforce the marginalization of Latinx students such as residential segregation and disproportionately low access to high quality early childhood education programming, similarly note the scapegoating of Spanish as justification for the outcome disparities observed in schooling. In short, opposition to bilingual education has typically taken on heavily ideological discourses about nationhood, citizenship, race, and ability that are overlaid into the subjugation of Spanish and bilingualism before an English monolingual agenda.

\section{Liberal multiculturalist discourses}

On a seemingly opposite end of a spectrum, certain discourses position bilingualism as valuable and desirable. Ruiz (1984), in seminal work that connected orientations toward linguistic diversity and subsequent language policy, offered the 'language as resource' orientation to capture this ideology, in stark opposition to an ethnoculturalist 'language as problem' orientation. Ruiz notes the benefits in diplomacy, national security, international commerce, educational parity, and social cohesiveness that could follow from greater promotion of societal 
bilingualism. Such discourses that affirm the value of bilingualism for societal, economic, and educative benefits can be termed 'liberal multiculturalist' (Flores 2015). A specific subset of such discourses are the specifically neoliberal discourses that frame bilingualism as a useful and marketable commodity in a globalized economy. These are narrower than liberal multiculturalism insofar as they orient entirely toward the commodification of language and market forces rather than also considering goals of social cohesion. Such discourses have gained a great deal of traction, as evidenced in growing popularity of dual language programs (García 2014), and the state of California's Senate Bill 1174 (SB-1174 2014, 93), which states, 'employers across all sectors, both public and private, are actively recruiting multilingual employees because of their ability to forge stronger bonds with customers, clients, and business partners.' While the range of liberal multiculturalist discourses indeed promote bilingualism and bilingual education, several authors have offered caution for their use (Flores 2015; Petrovic 2005).

Various scholars warn that decoupling bilingual education from a lens of cultural elevation for linguistic minority communities (not only Latinxs) and instead tying it to neoliberal goals of mobile and versatile workforces may undermine opportunities for social equity. This notice was first served by Valdés (1997b), who combined observations of dual language programs with research on schooling outcomes for Mexican- American children in the US to highlight the general failure to reconcile the goal of improving outcomes for Latinx youth with that of fostering the bilingualism of White, English-dominant students, noting less rigor in Spanish instruction and a failure to address the racial stratification of students in social spheres. Similarly, Petrovic (2005) and Flores (2013a) argue that resource-orientations toward language that leverage neoliberal discourses ultimately play into a broader conservative restoration in the United States by reinforcing free market principles that thus far have only served to marginalize linguistic minority communities. García (2014) notes how the authoritarian separation of languages and insistence on standardized forms within many dual language programs devalues the language practices of US Latinxs. Finally, Flores (2015), specifically distinguishes between this 'liberal multicultural' vision for bilingual education that subsumes the specific oppressions and needs of linguistic minority communities 
under colorblind notions of collective benefits and a 'race radical' vision rooted in the US Civil Rights Movement of the mid-2oth Century that actively contested racial and linguistic oppression.

These works inform our research by providing markers for classifying discourses. Defenses of bilingual education tied to economic advancement and globalization but oblivious to the racialization of language practices would indeed correspond to this liberal multiculturalist sphere. One lacking area in these studies, however, is how such discourses can be overtly turned against bilingual education, as opposed to simply subjugating the bilingualism of Latinxs to that of Whites. This work, reporting observations from written and verbal commentary during the Colorado Board of Education's discussion of proposed rule revisions to the READ Act that would remove requirements of English testing for students receiving literacy instruction in Spanish, provided the first example we have encountered of liberal multiculturalist discourses praising bilingualism in order to interject English into the curriculum earlier and in greater quantities in bilingual programming.

\section{Methods}

This study uses the methods of Critical Discourse Analysis (CDA). While there are various approaches within this methodology (for a review, see Rogers et al. 2005), we draw upon Gee's (1996) framework which distinguishes between 'big-D' Discourse (language forms and the cultural formations and norms associated with Discourses), and 'little d' discourse (specific linguistic elements that comprise such Discourses). Under this analytic lens, both types of discourse are inherently both ideological and political insofar as they are situated in historical patterns of practice and power relations (Rogers et al. 2005), with meanings and understandings being distributed and negotiated through social interaction (Gee and Green 1998). Thus, texts such as the READ Act revisions and the statements made in their regard during the Board of Education meeting at hand must be placed in dialogue with the conditions from which they emerge and to which they contribute, including recognition of prominent ideologies about Spanish, Latinxs, and bilingual education, and historical discursive patterns 
that have given shape to these shared social understandings. According to Fairclough (2001), such analysis calls for a three-tiered framework that considers the specific vocabulary, grammar, and textual structures of the text; the relational values of the text that cue the social relationships that it enacts; and the experiential and expressive values of the text or discourse that indicate the text producer's experience and evaluation, respectively, of the social world, (Fairclough 2001, 93). This method draws attention to ideologically contested terms, to the classification schemes relied upon or put in place, to the processes and participants emphasized, and to interactional conventions, among other elements. Such criteria enable the analyst to gauge how local language events emerge from, respond to, and cycle back into broader discourses.

\section{Setting and participants}

Data collection took place at a Board of Education meeting held on 8 April 2015. Offering comment in favor of the proposed rule revisions was an amalgam of teachers, district personnel, researchers, and advocacy organizations that had partnered specifically in response to the READ Act's initial implementation and its subsequent pressuring of bilingual programs to alter their instructional practices (for a detailed description of coalition members and the group's formation, see $\mathrm{Au}$ thor 2 \& Author 1, in press). Offering opposition to the rule revisions were two advocacy organizations (one devoted to literacy development and the other to education broadly), several private citizens including one identifying as a stakeholder and educator in local schools, and a former Department of Education official who worked in the Literacy Office. The Board of Education, a volunteer body elected by congressional district voters (although two members then were Republican gubernatorial appointments selected to complete a departed Board member's term), at the time consisted of four Republicans and three Democrats, and had split along party lines in votes on politically divisive issues. Board members had varied prior experience in education. Two of the four Republicans had served as classroom teachers (one went on to earn a doctorate and work as a professor and dean of a college of education before joining the Board), while two others (a former legal assistant and a former state legislator turned lobbyist) 
described deep involvement in their children's schools. On the Democratic side, two of three Board members were former teachers (one a World Language teacher, the other an ESL teacher who eventually earned a doctorate in education) and the third was a former tax CPA and college accounting professor who likewise derived her interest in education governance from volunteering at her children's schools.

Meanwhile, the role of the research team in this matter was as advocates. We were both members of a formal collaborative of faculty across institutions of higher education in the state who worked in the field of culturally and linguistically diverse education (Higher Educators in Linguistically Diverse Education, or HELDE). The group formed to share ideas and best practices around teacher preparation and to offer collective expertise to state and district officials on matters such as teacher evaluation and assessment policy for emergent bilinguals. The group was not formally an advocacy organization, but had participated in prior policy engagement, including some members who were part of the No-on-31 mobilization, and submitted one of the written comments in favor of the rule revisions. In addition, one of us (Author 1) was a board member of the Colorado Association for Bilingual Education, an educational civil rights organization advocating for emergent bilingual students, families, and their teachers. Clearly, both of us were invested in passage of the revised rules and were familiar with the arguments often deployed in opposition to bilingual education. Moreover, we had professional relationships with representatives of the school districts that wrote in favor of the revisions, although we did not play any part in the composition of these statements. In the Findings section that follows, we begin by situating the comments and discussion within the original text of the READ Act and of the proposed revisions. We follow by examining the discourses both familiar and novel that reified both positive and negative social ideologies about bilingualism, bilingual education, and Latinx students.

\section{Data collection}

We analyzed a corpus consisting of the written comments submitted to the Board of Education and the transcribed discussion that preceded the Board's vote on the rule revisions (transcription conventions correspond to 'broad' transcription of discourse, [Du Bois et al. 1992]), 
the READ Act's original text, and the letter written by the state's Attorney General stating that the law did not require testing in English. Eight comments were submitted: three in favor of the revisions, five opposed. Of the five opposed, however, two misinterpreted the revisions to apply to all students classified as English Learners, and not only to those in bilingual programs whose literacy instruction was in Spanish. Thus, these comments were disregarded in the analysis. Coding was conducted with a priori codes drawing on the aforementioned discourses from the literature both in favor of bilingual education and against it. Here, we focus on those used to undermine bilingual education that appeared in written comments and oral statements made in opposition to the rule revisions. In coding, however, one new discursive move arose. Whereas liberal multiculturalist discourses that frame bilingualism as a resource have often been used as a way to advocate for bilingual education without linking it to Latinx ethnolinguistic vitality or linguistic rights, in this case they were being used as a justification to introduce English assessments, and by extension, English, into the curriculum at earlier grades and to justify additional testing and monitoring of bilingual programs.

\section{Findings}

We begin by contextualizing the Board's discussion and vote with the original verbiage of the act and the proposed rule revisions. The central provision stipulating demands and accountability for reading proficiency in students grades $\mathrm{K}-3$ reads as follows,

It is therefore the intent of the General Assembly that each local education provider that enrolls students in kindergarten or first, second, or third grade will work closely with the parents and teachers of these students to provide the students the instructional programming, intervention instruction, and support, at home and in school, necessary to ensure that students, by the completion of third grade, can demonstrate a level of competency in reading skills that is necessary to support them in achieving the academic standards and expectations applicable to the fourth grade curriculum (Colorado READ Act, 22-7-1202. (2), 2012) 
The legislation also provides for the potential retention of students not attaining this level of proficiency (what the bill labeled a 'significant reading deficiency'). In order to diagnose said 'significant reading deficiencies,' the bill prescribes that 'each local education provider. . .shall ensure that teachers measure each student's reading competency using interim assessments at least once during the spring semester' (22-7-1205[1] [a]) and that such assessments are to be selected from a list of approved assessments outlined by the Board. Selected assessments must meet specific criteria, outlined in section 22-7-1209(2) (a)(II)(B), which reads,

Each of the recommended reading assessments is valid and reliable and proven to effectively and accurately measure students' reading skills in the areas of phonemic awareness; phonics; vocabulary development; reading fluency, including oral skills; and reading comprehension.

Any critique of the framing of literacy as discrete skills developed on an individual cognitive level is beyond the scope of this paper (see Lea and Street 2006, for a sociocultural perspective of literacies as situated social practices). The importance of this clause, rather, is that it establishes parameters for available assessments for READ Act compliance. Section 22-7-1209(2)(a)(II)(D) elaborates on these criteria by making specific provisions for emergent bilinguals, 'At least one of the recommended reading assessments for kindergarten, first, second, and third grades is normed for the performance of students who speak Spanish as their native language, which assessment is available in both English and Spanish.'

The caveat in this latter criterion was that the Board of Education, when proposing initial regulations, chose to interpret it as a requirement that testing be conducted in English with the possibility to additionally test in Spanish for students for whom it was necessary. Thus, students in bilingual programs receiving most or all of their literacy instruction in Spanish still would be tested in English as a certainty and only in Spanish if the district opted for double testing. Noting that English testing would likely yield invalid results and risk overrepresentation of emergent bilinguals as significantly reading deficient, in turn deterring schools from offering maintenance 
bilingual programs or any bilingual programming at all, a coalition of researchers, educators, and advocacy organizations pushed for revisions to the proposed regulations. The revisions addressing this matter inserted clause 9.01(E) regarding approved interim reading assessments, which stated,

As reading comprehension is dependent upon students' understanding of the language, children with limited English proficiencies, as determined by the individual district's criteria and documentation, must be assessed in their language of reading instruction, leading to their proficiency in reading English. (Colorado State Board of Education 2015, 12)

This proposed rule revision would eliminate the unnecessary double testing and eliminate the disincentive for bilingual education entailed by mandatory English testing. The debate preceding the vote on the rule revisions mostly showcased familiar patterns, but the opposition to the revisions, and by extension to bilingual education generally, deployed a frequent discourse used in favor of bilingual education to instead undermine it.

\section{Discourses in favor of bilingual education}

Perhaps echoing the strategic approach of the No-on-31 campaign, support for the rule revisions mostly avoided tying the discussion to a broader referendum on bilingual education. Instead, written comments and board discussion hew very closely to discourses about assessment validity. Three written comments were submitted to the Board in favor of the proposed revision. Two were from school districts and one was from a consortium of researchers at institutions of higher education.

Boulder Valley School District (BVSD, 2015), a relatively affluent district with $10.4 \%$ of students classified as Hispanic and $1.4 \%$ classified as English Learners, submitted a statement exclusively addressing the fact that the READ Act sought to measure literacy, not English proficiency, and that Spanish assessments for students in SpanishEnglish bilingual programs were thus suitable. 
The changes will have a very positive impact on a great many of our second language learners in the Boulder Valley School District, as well as for students across the state in bilingual programming. The changes to the rules will allow us to use Spanish reading assessments to determine whether a child has a significant reading deficiency. . . The READ Act law is designed to ensure that students are learning to read, a skill which can be measured by a student's dominant language. The law specifically allows for the use of Spanish assessment, a sentiment confirmed by the Attorney General's formal opinion. As such, we believe that it is in the best interest of our students that the READ Act Rules be amended to directly reflect the law. All four domains of English language acquisition will of course, continue to be measured through ACCESS for all ELLs, in accordance with best practices as well as State and Federal law.

By mentioning that the proposed rule changes benefit all students in bilingual programming, the BVSD statement acknowledges that the double testing under current rules installed hindered bilingual education. Nevertheless, the statement emphasizes the law's verbiage, the Attorney General's opinion disambiguating between literacy and English language development, and assurances of students' continued monitoring for English language development. In doing so, the statement reflects discourses of scientific evidence and validity, both of which permeate educational policy. In the landmark opinion of Castañeda v. Pickard (648 F. 2 [1981]), the Fifth District Court in Texas established a three-pronged test to assess the legitimacy and quality of programs serving EL-classified students, with the first prong being that 'the court must examine carefully the evidence the record contains concerning the soundness of the educational theory or principles upon which the challenged program is based' (18). Three decades later, the No Child Left Behind Act (NCLB) stipulated that assessments used to measure school accountability within states must adhere to strict technical requirements for validity and reliability. 
(3) Academic Assessments - [. . . ]

(iii) be used for such purposes for which such assessments are valid and reliable, and be consistent with relevant, nationally recognized professional and technical standards;

(iv.) be used only if the State educational agency provides the Secretary evidence from the test publisher or other relevant sources that the assessments used are of adequate technical quality for each purpose required under this act (NCLB, 2001, Sec. 1111. (3)[b](iii-iv), 26)

Thus, the prevalent discourse is one of technical precision and valid evidence more so than anything about the inherent value of bilingualism and bilingual education. If anything, consistent with a LatCrit framing that recognizes how legal and institutional frameworks systematically marginalize Latinxs, the statement reifies the prioritization of English by assuring adherence to progress monitoring and use of the ACCESS test.

Similarly, the statement from Higher Educators in Linguistically Diverse Education (Higher Educators in Linguistically Diverse Education 2015), a consortium of faculty from institutions across the state, emphasizes the greater validity of literacy assessments in Spanish for Spanish-dominant students receiving literacy instruction in Spanish.

Members of our organization have published important research on practices in Colorado related to identifying "SRDs" for bilingual students and found that when a students' bilingualism is not taken into account, a great deal of over-identification of "SRDs" occurs where these so called 'reading deficiencies' actually do not exist (Hopewell and Escamilla 2014). The problem with this over-identification is that students do not receive the appropriate supports for what they need when they are identified as having an "SRD" but are actually on the appropriate trajectory towards academic English proficiency, or even better, full biliteracy. Mislabeling and misdiagnosing "SRDs" in bilingual students wastes their time in interventions targeted at reading development when what they need is language development opportunities. 
Once again, the salient theme in the submitted comment is one of evidence validity, although this particular statement does espouse a favorable view of biliteracy and harkens to discourses of overrepresentation of emergent bilinguals and racial minorities, including Latinx students, in remedial and Special Education tracks with the mention of 'overidentification.' This clearly evokes the language from the May 25th Memorandum, which states 'School districts must not assign national origin minority group students to classes for the mentally retarded on the basis of criteria which essentially measure or evaluate English language skills' (DHEW 1970, 1).

The final statement, submitted by Denver Public Schools (DPS 2015), by far the largest school district in the state and the one with the largest number of EL-classified students in bilingual programming, echoed these discourses of validity but with some defense of bilingual programming.

The purpose of the READ Act is to ensure students become proficient in the skill of reading[...]

DPS wants to be able to accurately diagnose significant reading deficiencies for students in their primary language of instruction so we can ensure we are providing the right interventions and supports. We are committed to bi-literacy for two reasons; we see language as an asset, and our student achievement data suggests that students benefit from our Bilingual model. While we understand and are dedicated to the importance of ensuring that all students can read and write proficiently in English, we also believe that enhancing a student's skills in Spanish is a benefit to our students and our community $[\ldots]$

An analysis of ACCESS Trajectory results in DPS at the elementary level shows that Spanish-speaking ELs are most likely to be On-Track to become English proficient if they are in Bilingual instruction.

In its statement, DPS invokes discourses of evidence and validity in terms of evaluating literacy with Spanish assessments for students to 
whom this would be appropriate. Moreover, DPS marshals both national and internal data to support its bilingual programs and argues that the ability to have Spanish assessments guide instruction is crucial to the effectiveness these programs have thus far demonstrated compared to Sheltered English alternatives. However, this statement also subsumes bilingual education to some extent as a scaffold for English language development ('Spanish-speaking ELs are most likely to be On-Track to become English proficient if they are in Bilingual instruction'), and may be adopting some of the neoliberal framings that position bilingualism as an economic resource above a cultural affirmation (Flores 2015; Petrovic 2005) or an asset in stating, 'we also believe that enhancing a student's skills in Spanish is a benefit to our students and our community,' although the nature of such benefit is left unexplained. Indeed, as Delgado Bernal (2002) observed in her interviews with Latinx students, bilingualism and biculturalism was specifically praised not only for its utility in English language development but also because of its value strengthening family and community ties. Thus, arguments in favor of the rule revisions mostly emphasize discourses of scientific evidence and validity about assessments and instructional programming.

We return here briefly to our cautions and limitations of the debate at hand. The imposition of English literacy tests in the early grades for emergent bilingual students receiving literacy instruction in Spanish indeed posed a threat to the viability of bilingual programming in districts given the potential for high rates of designation as Significantly Reading Deficient. By invoking discourses of validity and scientific measurement and by not challenging the heavy reliance on phonics and standardized language forms in the Spanish tests presented as alternatives, proponents of the rule revisions adhered to colorblind notions of equity that ignored the roles that ideologies of race and language play in defining educational experiences and benchmarks of proficiency. Scholars of LatCrit remind us that these have historically been detrimental to Latinx students and particularly those who are emergent bilinguals acquiring English in schools (Delgado Bernal 2002; Solórzano, Villalpando, \& Oseguera, 2005). Such narrow perspectives, while useful and perhaps necessary in this particular debate given the political climate hostile to bilingual education, ultimately maintain patterns of subjugation and social reproduction. 
Grinberg and Saavedra (2000), for instance, offer a genealogical analysis of bilingual and ESL (English as a Second Language) education as disciplinary fields and as implemented in New Mexico by way of critique. They point to the ways in which such programs glorified Spanish history and linguistic practices over the indigenous and Chicanx cultural influences in the region, the resource disparities encountered by Latinx bilingual students and their educational programs as the academic fields of bilingual education and ESL emphasized linguistics and language pedagogies over cultural/systemic critique, and the reification of social hierarchies when knowledge of academics was prized over the resources bilingual communities could bring to bear on their own schools. Thus, while proponents of the rule revisions indeed advocated for their bilingual learners, they did so in manners that left untouched the racist and classist notions undergirding ideas of standardized language. With that caveat, we proceed to examine the familiar discourses giving shape to ideologies opposed to and in favor of bilingual education before turning to the newly emergent discourse that coopted neoliberal pro-bilingual education arguments to undermine bilingual programming.

\section{Traditional arguments against bilingual education}

Despite the aforementioned shortcomings in the arguments for the rule revisions, they must be weighed against the arguments opposed, which sought ultimately to undermine the whole endeavor of bilingual education. The first and most obvious set of discourses on display in the discussion of the proposed READ Act revisions, (which, again, would allow bilingual programs to assess students in their language of instruction and without additional, likely invalid English testing), were those reiterating previous oppositional stances and their ethnoculturalist orientations. At the heart of opposition to the rule revisions within these discourses were claims that bilingual education would delay English acquisition and literacy development and affirmations of English as the only valid language of knowledge or academics, consistent with the history of marginalization that Latinx students have encountered in US schools (Sólorzano, Villalpando, and Oseguera 2005). Such claims are evident in both the written comments and the Board's discussion prior to voting on the rules. 
Within the ethnoculturalist discourse of English as the lone acceptable language of a US identity are assumptions about how this English is to be acquired. Opponents of bilingual education often maintain that complete immersion into the target language is the best means of instruction. Statements to this effect abounded in the written statements and in Board member commentary. One non-profit organization (Science Core Group 2015) advocating improved literacy attainment, for example, included in its written comment the following statements,

I can assure you, there is no research that indicates this would enhance students' learning of English. In fact, it will only prolong not mastering the ability to attain English literacy proficiency [...]

What was once a valid assumption - that Spanish-speaking students would be best taught Spanish as an academic language first and then transitioned to English - no longer is the appropriate construct.

The first statement, counter to the prevalent research on bilingual education, denies the benefits of this curricular arrangement by claiming that it will in fact delay English acquisition. The second statement, meanwhile, specifically targets US Latinx students by suggesting that their bilingualism undermines the value of bilingual education by putting them in contrast to recently immigrated students who are monolingual Spanish users. Focusing on the experiential value of the statements (Fairclough 2001), we observe the evident beliefs of the authors of this written comment with respect to how language is acquired and by whom. Moreover, in the relational dimension, whereby the text is connected to other social identities in the field of its production, we further note an appreciably overt connection made between the language of testing and the language of instruction. The comment opposes the proposed rule changes that allow testing in one language or another (rather than requiring it in English and allowing for supplementary testing in Spanish) by appealing to a broader discourse of opposing bilingual education altogether.

A similar offering was made in the written comments submitted by a private citizen (Melton 2015) claiming to be an educator in the state. 
The commenter, a former teacher and literacy interventionist, argued,

I believe that all of the educators in this country should place a priority on students becoming proficient in English. Good bilingual education is not education in students' native language, it is education that develops students' proficiency in both languages simultaneously [. . . ]I urge you to consider the extremely negative impact that these proposed changes will have in ensuring that ALL students in Colorado can read by the end of 3 rd grade.

The literal reading of this text demonstrates a fundamental misunderstanding of the benefits conferred for second language acquisition and academic achievement through sound maintenance and development of the primary language insofar as it asserts that assessing in Spanish will preclude children's ability to read by the end of 3rd grade. In addition, the statement positions literacy in Spanish as inferior to literacy in English or as invalid in its entirety given that English proficiency is prioritized over bilingualism and positioned as integral to reading ability overall. The proposed rule changes, after all, would not do away with accountability measures for literacy, but rather would provide districts with the option to test students in their language of literacy instruction. Thus, this comment engages in discourse that displays and constitutes ideologies of the higher value of English monolingualism over Spanish or even bilingualism, even though the latter is preferable for Spanish-dominant students learning English in schools.

This broader idea, that English is the sole language of value in schooling, was reinforced in the third submitted comment. Offered by another non-profit organization (Literate Nation 2015) that also advocated for literacy supports, the comment states,

Since Colorado READ is focused academic language [sic], the assessment should be in the academic language (as long as the assessment is not burdensome). Assessing Spanishspeaking children in English using a short test is likely to determine if these students have, even in first grade, developed the necessary academic language needed to make progress. 
This statement, like those in the other written comments, positions English as the lone medium for development of literacy skills and as the only language of value in schooling. This point was further made in the Board members' discussion (CBE, 2015), when one member offered,

105 I've never been in a classroom where

106 even if it were bilingual

107 meaning if, if, if the instruction were in another language

$108 \rightarrow$ you also have to start very early with English

$109 \rightarrow$ and they must be able to get to a certain point in

English

110 to

111 or else

112 I just don't see how

113 by third grade

114 many kids have to take uh

115 in three years they have to take their tests in English

The telling utterances in this transcript occur in lines 108 and 109 of the transcribed Board discussion, wherein the Board member conflates language acquisition and literacy skills as a means to interject English in the curriculum sooner. As noted in a letter by the state's Attorney General to the Board on the issue,

The purpose of the READ Act is to ensure that students become proficient in the skill of reading. There are other provisions of law that seek to encourage and test proficiency in understanding the English language, but the READ Act's focus is on the skill, not the language in which it is employed. (Suthers, August 12, 2014, 2-3).

With this letter and its entailed clarification of statute before the Board, continued efforts to intertwine English language acquisition with literacy development and to subjugate literacy in Spanish to that in English betrays an ethnoculturalist orientation that places English in higher status and as the primary acceptable medium of instruction 
for emergent bilingual Latinx students. Such maneuvers, recurrent in the history of education in the United States, exemplify the ways that language, race, and national origin are conflated, and used as vectors of discrimination against Latinx students (Yosso et al. 2001).

\section{Coopted liberal multiculturalist discourses}

By adopting the discourse of liberal multiculturalism, a number of statements made by Board members seemingly value bilingualism and have in mind the best interests of bilingual students. Indeed, on their sentence-level meaning, they could be taken as statements of genuine concern. However, when analyzed on the relational level that connects them to external texts and the expressive level that connects the speakers to social identities outside the text, the agenda belying these statements is clear. One example of this invocation of liberal multiculturalist discourses to subvert bilingual education is offered in the following statement, uttered by one of the Board members arguing that English testing was a necessary component of effective bilingual instruction.

403 When I look at the data

404 for ELL students

405 When you look at the 1oth grade data

$406 \rightarrow$ These students are being grossly underserved in this state

$407 \rightarrow$ We need their bilingualism

408 We need to know that they're achieving

409 in English and Spanish

In lines 406 and 407 of this declaration, we observe an evident statement of concern both for the current inequitable outcomes experienced by Latinx students and for the inability to dutifully foster their bilingualism as a resource. Nevertheless, this sentiment is promptly undermined by the intentions of the utterance in line 409, wherein the insistence on testing in English is presented as necessary to this undertaking. This same Board member revisited this idea in a subsequent comment. When reminded by other Board members that there was already a test in place to evaluate students' English language 
development, including reading skills sensitive to different stages of English proficiency, and that literacy skills could be acquired in other languages and that testing students in bilingual programs whose literacy instruction was not in English in this manner could lead to misidentification of students as Significantly Reading Deficient (per the labeling of the statute), she responded,

456 If we wanna pull up

457 the actual items on the test [referring to the ACCESS

test for English language development]

458 it is not a literacy assessment.

$459 \rightarrow$ So I would like to know

$460 \rightarrow$ That we're supporting bilingualism,

$461 \rightarrow$ biliteracy

$462 \rightarrow$ and ELL achievement

$463 \rightarrow$ in the state.

464 And when you look at the data in the state,

465 it's abysmal.

466 And to me

467 these rules

468 set us back

469 substantially

Once more, the Board member is reiterating the widespread achievement disparities of bilingual students (ignoring that the vast majority of such students are in fact not enrolled in bilingual programs but rather in Sheltered English Immersion instruction) and appealing to these conditions to justify English testing, notable in lines 459-463. This discursive move reflects an early comment made by a separate Board member near the outset of the discussion, who offered,

31 If we value

32 bilingualism

33 why would we not test

34 a Spanish speaking student

35 in English

36 until after the third grade? 
This statement, made by the same Board member who off-handedly remarked about Latinx students knowing neither English nor Spanish, first introduces the notion that testing in English and Spanish is the only sure way to monitor progress in literacy development for the purposes of READ Act accountability. While this early utterance does not make the same assertive claims about bilingualism being a necessity and underdeveloped resource, it appeals to the same notion that testing in two languages ensures learning in two languages. The reality, of course, is quite different, as the Board members were reminded by the Department of Education employee tasked with overseeing READ Act implementation and charged with answering Board members' questions during this discussion. Presenting a concrete example of the coercive mechanism of testing in language curriculum that Menken (2006, 2008), Menken and Solorza (2014), and Shohamy (2006) describe, this employee responded to the question of why the proposed rule revisions were necessary if the existing rules allowed Spanish testing to supplement (but not supplant) English testing.

$552 \rightarrow$ This was interpreted in the field

$553 \rightarrow$ as even if you have a kindergartener

$554 \rightarrow$ who is fluent in Spanish

$555 \rightarrow$ and doesn't know English

$556 \rightarrow$ You give them the English version

$557 \rightarrow$ And you say

$558 \rightarrow$ If they can't finish it

$559 \rightarrow$ that kid has a significant reading deficiency.

56o The kid might read perfectly well

561 in Spanish,

$562 \rightarrow$ but they interpreted our regs to say

$563 \rightarrow$ No.

$564 \rightarrow$ You have to make that determination

$565 \rightarrow$ based solely on English.

566 That was the original question posed

567 and the answer was,

568 No.

569 You're not actually looking at English acquisition

570 What you're looking at is reading and literacy

acquisition, 
571 and in grades $\mathrm{K}-3$

572 it's possible that

573 there could be kids

574 who don't have a reading deficiency,

575 they just are reading in a different language

Lines 552-559 and 562-565 of the transcript make perfectly clear the tension between regulatory options for testing in Spanish and actual implementation in the field. If English testing and reporting of scores in English are compulsory, then there is a logical assumption that such tests and scores are of consequence, even if Spanish testing could be used to contest findings in English of a Significant Reading Deficiency. This protocol puts students through an undue burden of additional and invalid testing as well as the possible stigma and anxiety of a poor test performance, while likewise burdening schools and districts to administer the extra test and compose rationales for differences in scores across languages. Such impositions on instructional time and administrative bandwidth may explain why implementation of READ Act accountability measures among educators erred on the side of over-identifying reading deficiencies in bilingual students. Such designation could carry with it requirements that students receive additional targeted reading instruction (which, if a student's low score was solely due to being at early stages of English language development, would amount to misspent instructional time) and even possibly grade retention. Thus, while appeals to include testing in English for literacy skill development may have expressed literal appreciation for bilingualism and concern for bilingual students' academic success, their relational purpose was quite the opposite. The observations from implementation and clarification from the Department of Education and the Attorney General leave little ambiguity that such appeals are in fact indexing social identity positions opposed to bilingual education given the inevitability of over-identifying students with significant reading deficiencies. Even in the dire warnings offered by Flores (2013a) and Petrovic (2005), the use of liberal multiculturalist discourses has not been positioned as so directly antagonistic to bilingual education, and it is important to recognize this coopting. 


\section{Discussion}

Our analysis leaves us with three principal takeaways. First, this serves as a reminder of the way that assessment can serve as language policy. While this specific case discusses reading tests in Colorado, it reflects observations of standardized testing nationally and language testing globally whereby tests reify the linguistic practices deemed valuable and, in effect, marginalizing users of unassessed varieties. In this instance, testing in English, while not directly restricting instruction in Spanish, has the effect of discouraging and penalizing it. Second, liberal multiculturalist discourses that promote bilingualism on economic terms are subject to coopting. While bilingualism may indeed have economic value in a globalized economy, English holds a privileged position in the US and increasingly the world. Thus, these neoliberal discourses can simultaneously purport to support bilingualism while encouraging English take a more central role in the curriculum at the expense of other languages in multilingual education models. This was clearly visible in districts' stated pressure to abandon bilingual programming after passage of the READ Act prior to the revision of the rules that allowed testing in the language of instruction. Finally, the insistence on, at best, double testing this particular group of students in Spanish and English, even when an English test would almost certainly provide invalid and unreliable data for students at early levels of English language development and receiving literacy instruction in Spanish, speaks to the surveillance under which emergent bilingual Latinx students live in US schools. As the assimilationist ideologies aforementioned would hold, the language of these students is monitored and judged disproportionately to that of peers who are English monolinguals or even bilingual students in assimilationist instructional models.

These observations provide simultaneous insights. The first and most obvious is the manner in which overt praise for bilingualism can in fact mask covert efforts to discourage it in schools as just discussed. The second, meanwhile, is the way in which advocates for bilingual education may themselves be perpetuating Latinx and/ or emergent bilingual students' marginalization by agreeing to the very terms of the debate. Advocates of the rule revisions only questioned the need to test in English in the early grades rather than the structure 
of the specific tests in either language (focused on phonics and standardized forms) or the larger regime of standardized testing that presumes predictable and linear development along hypothesized developmental sequences (see Cumming 2008 for a thorough critique of language proficiency testing). In so doing, the subjugation of racialized Latinx language practices beneath idealized monolingual forms (García 2009b) in curriculum and in social interaction even within bilingual programs was left untouched. While such compromises may indeed be necessary in urgent policy questions, advocates cannot be satisfied with such piecemeal victories. The goal, especially for researchers with the privilege of social capital afforded by their positions, should be to push beyond the debates at hand and towards more just visions of schools and society.

Disclosure - No potential conflict of interest was reported by the authors.

\section{Authors}

Luis E. Poza is an Assistant Professor of Teacher Education at San José State University. Previously, he served in the program in Culturally and Linguistically Diverse Education at the University of Colorado Denver. His research focuses on language ideologies as they manifest in educational practice and policy, particularly with respect to Latinx multilingual learners and their schooling experiences. He is a former elementary school teacher, a National Academy of Education/Spencer Foundation Postdoctoral Fellow, a member of the Working Group on ELL Policy (http:// ellpolicy.org) that conducts and applies research regarding education of emergent bilinguals in partnerships with states and districts, and a board member of the Colorado Association for Bilingual Education.

Kara M. Viesca is an Assistant Professor of Teaching, Learning and Teacher Education at the University of Nebraska Lincoln. Her research focuses on advancing equity in the policy and practice of educator development, particularly for teachers of multilingual students. She is the Principal Investigator/Project Director of the International Consortium for Multilingual Excellence in Education, a 5-year project providing teachers in 11 states and several countries in Europe with access to professional learning eWorkshops for educators regarding effective practices with multilingual students in K-12 classrooms and schools. 


\section{References}

Abedi, J. 2002. "Standardized Achievement Tests and English Language Learners: Psychometrics Issues.” Educational Assessment 8 (3): 231-257. doi:10.1207/ S15326977EAo803_02.

Abedi, J., and P. Gándara. 2006. "Performance of English Language Learners as a Subgroup in Large-Scale Assessment: Interaction of Research and Policy." Educational Measurement: Issues and Practice 25 (4): 36-46. doi:10.1111/j.1745-3992.2006.00077.x.

Bell, D. 1980. "Brown V. Board of Education and the Interest-Convergence Dilemma." Harvard Law Review 93 (3): 518-533. doi:10.2307/1340546.

Benjamin, R. 2009. Searching for Whitopia: An Improbable Journey to the Heart of White America. New York, NY: Hyperion.

Bilingual Education Act of 1968. Elementary and Secondary Act Amendments, Pub. L. No. 90- 247, Title VII, §702, 81Stat. 816. (1968).

Boulder Valley School District. "Proposed Rule Changes to READ Act." Written public comment at the meeting of the Colorado Board of Education. Accessed April 8, 2015. http://www.boarddocs.com/co/cde/Board.nsf/ files/9VBMEB 58BCBD/\$file/3.17.15\%20Proposed $\% 20$ Rule $\% 20$ Changes $\% 20$ to\%20READ\%20Act.pdf

Castañeda, V. P., 648 F. 2 (1981).

Colorado Department of Education (CDE). (2017). "Colorado READ Act.” Accessed https://www.cde.state.co.us/coloradoliteracy

Colorado State Board of Education. "Rules for the Administration of the Colorado Reading to Ensure Academic Development Act (READ ACT): Recommended Revisions.” Accessed February3, 2015. https://www.cde.state.co.us/ coloradoliteracy/readrules3916

Colorado State Board of Education. (2015). "State Board of Education Meeting 4/ o8/15pt. 4." Accessed September 23, 2016. https:/www.cde.state.co.us/ cdeboard/sbemeeting-20150408-pt4

Cumming, A. 2008. “Assessing Oral and Literate Abilities.” In Encyclopedia of Language and Education: Language Testing and Assessment, edited by E. Shohamy and N. Hornberger, 3-18. New York, NY: Springer.

Del Valle, S. 2003. Language Rights and the Law in the United States: Finding Our Voices. Vol. 40. Clevedon, UK: Multilingual Matters.

Delgado Bernal, D. 2002. "Critical Race Theory, Latino Critical Theory, and Critical Raced- Gendered Epistemologies: Recognizing Students of Color as Holders and Creators of Knowledge." Qualitative Inquiry 8 (1): 105-126. doi:10. 1177/107780040200800107.

Denver Public Schools. “DPS Support of READ Act Rule Changes.” Written public comment at the meeting of the Colorado Board of Education. Accessed April 8, 2015. http://www.boarddocs.com/co/cde/Board.nsf/ files/9VBMEJ58BEEo/\$file/4.2.15\%20Denver $\% 20$ Public $\% 20$ Schools $\% 20$ READ\%20Act\%20Rule\%20Change\%20Support\%20Letter.pdf 
DHEW (Department of Health, Education, and Welfare). (1970). Memorandum: Identification of Discrimination and Denial of Services on the Basis of National Origin, May 25. https://www2.ed.gov/about/offices/list/ocr/docs/lau1970. $\underline{\text { html }}$

Du Bois, J. W., S. Cumming, S. Schuetze-Coburn, and D. Paulino, Eds. 1992. Discourse Transcription. Santa Barbara Papers in Linguistics V. 4. Santa Barbara: Department of Linguistics, University of California.

Durán, R. 2008. "Assessing English-Language Learners' Achievement." Review of Research in Education 32 (1): 292-327. doi:10.3102/0091732X07309372.

Escamilla, K., S. Shannon, S. Carlos, and J. García. 2003. "Breaking the Code: Colorado's Defeat of the Anti-Bilingual Education Initiative (Amendment 31)." Bilingual Research Journal. 27 (3): 357-382. doi:10.1080/15235882.2003.10162 599.

Fairclough, N. 2001. Language and Power. 2nd ed. Essex, UK: Pearson Education.

Flores, N. 2013a. "The Unexamined Relationship between Neoliberalism and Plurilingualism: A Cautionary Tale.” TESOL Quarterly 47 (3): 500-520. doi:10.1002/tesq.114.

Flores, N. 2013b. "Silencing the Subaltern: Nation-State/Colonial Governmentality and Bilingual Education in the United States." Critical Inquiry in Language Studies 10 (4): 263-287. doi:10.1080/15427587.2013.846210.

Flores, N. 2015. "A Tale of Two Visions: Hegemonic Whiteness and Bilingual Education.” Educational Policy 30 (1): 13-38. doi:10.1177/o895904815616482.

Flores, N., and J. Rosa. 2015. "Undoing Appropriateness: Raciolinguistic Ideologies and Language Diversity in Education." Harvard Educational Review 85 (2): 149-171. doi:10.17763/o017-8055.85.2.149.

Galindo, R. 1997. "Language Wars: The Ideological Dimensions of the Debates on Bilingual Education.” Bilingual Research Journal 21 (2/3): 163-201. doi:10.1080 /15235882.1997.10668659.

Gándara, P. C., and F. Contreras. 2009. The Latino Education Crisis: The Consequences of Failed Social Policies. Cambridge, MA: Harvard University Press.

García, O. 2009a. “Livin’ and Teachin' La Lengua Loca: Glocalizing US Spanish Ideologies and Practices." In Language Allegiances and Bilingualism in the US, edited by M. R. Salaberry, 151-171. Bristol, UK: Multilingual Matters.

García, O. 2009b. "Racializing the Language Practices of US Latinos: Impact on Their Education.” In How the United States Racializes Latinos: White Hegemony and Its Consequences, edited by J. A. Cobas, J. Duany, and J. R. Feagin, 101-115. Boulder, CO: Paradigm Publishers.

García, O. 2014. "US Spanish and Education: Global and Local Intersections." Review of Research in Education 38 (1): 58-80. doi:10.3102/0091732X13506542.

Gee, J. P. 1996. Social Linguistics and Literacies: Ideology in Discourses. 2nd ed. Taylor \& Francis: London. 
Gee, J. P., and J. L. Green. 1998. "Chapter 4: Discourse Analysis, Learning, and Social Practice: A Methodological Study." Review of Research in Education 23 (1): 119-169.

Grinberg, J., and E. R. Saavedra. 200o. "The Constitution of bilingual/ESL Education as a Disciplinary Practice: Genealogical Explorations." Review of Educational Research 70 (4): 419-441. doi:10.3102/00346543070004419.

Higher Educators in Linguistically Diverse Education. 2015. HELDE Comments on READ Act Rules. Written public comment at the meeting of the Colorado Board of Education. Denver, CO, April 7. http://www.boarddocs.com/co/cde/Board. nsf/files/gVCL4754AFDo/\$file/HELDECommentsonREADActRules.pdf

Hill, J. H. (1995). "Mock Spanish: A Site for the Indexical Reproduction of Racism in American English." Language \& culture symposium. Accessed September 23, 2016. http://languageculture.binghamton.edu/symposia/2/part1/

Hill, J. H. 1998. "Language, Race, and White Public Space." American Anthropologist 100 (3): 680-689. doi:10.1525/aa.1998.100.3.680.

Hopewell, Susan, and Kathy Escamilla. 2014. "Biliteracy Development in Immersion Contexts." Journal of Immersion and Content-Based Language Education 2 (2): 181-195. doi: 10.1075/jicb.2.2.02hop.

Huntington, S. P. 2004. Who are We?: The Challenges to America's National Identity. New York, NY: Simon and Schuster.

Iglesias, E. M. 1996. "Foreword: International Law, Human Rights, and LatCrit Theory.” The University of Miami Inter-American Law Review 28: 177-213.

Irvine, J. T. 1989. "When Talk Isn't Cheap: Language and Political Economy." American Ethnologist 16 (2): 248-267. doi:10.1525/ae.1989.16.2.02aooo40.

Johnson, E. 2005. "Proposition 203: A Critical Metaphor Analysis." Bilingual Research Journal 29 (1): 69-84. doi:10.1080/15235882.2005.10162824.

Kroskrity, P. V. 2004. "Language Ideologies.” In A Companion to Linguistic Anthropology, edited by A. Duranti, 496-517. Malden, MA and Oxford, UK: Blackwell Publishing.

Lau, V. N., (1974). 414 U.S. 563, 94 S. Ct. 786, 39 L. Ed. 2 d 1.

Lea, Mary R., and Brian V. Street. 2006. “The 'Academic Literacies' Model: Theory and Applications." Theory into Practice 45 (4): 368-377. doi:10.1207/ s15430421tip4504_11.

Literate Nation. "Literate Nation Letter Re: READ Act. Written Public Comment at the Meeting of the Colorado Board of Education." Accessed April 8, 2015. http://www.boarddocs.com/co/cde/Board.nsf/ files/9VBMDD58B349/\$file/2.17.15\%20Literate\%20Nation\%2oLetter\%20 re\%20READ\%20Act.pdf

Macías, R. F. 2014. "Spanish as the Second National Language of the United States Fact, Future, Fiction, or Hope?." Review of Research in Education 38 (1): 33-57. doi:10.3102/0091732X13506544.

Melton, B. 2015. Change to READ Act Rules. Written public comment at the meeting of the Colorado Board of Education. Denver, CO. http://www. boarddocs.com/co/cde/Board.nsf/files/9VBMDP58B615/\$file/3.2.15\%20 Change\%20to\%20READ\%20Act\%20Rules.pdf 
Menken, K. 2006. “Teaching to the Test: How No Child Left behind Impacts Language Policy, Curriculum, and Instruction for English Language Learners." Bilingual Research Journal 30 (2): 521-546. doi:10.1080/15235882.2006.10162 888.

Menken, K. 2008. English Learners Left Behind: Standardized Testing as Language Policy. Vol. 65. Clevedon, UK: Multilingual Matters.

Menken, K., and C. Solorza. 2014. "No Child Left Bilingual: Accountability and the Elimination of Bilingual Education Programs in New York City Schools." Educational Policy 28 (1): 96-125. doi:10.1177/0895904812468228.

NCLB (No Child Left Behind) Act of 2001, P.L. 107-110, 20 U.S.C. § 6319 (2002).

Nieto, D. 2009. "A Brief History of Bilingual Education in the United States." Perspectives on Urban Education 61: 61-65.

Ovando, C. J. 2003. "Bilingual Education in the United States: Historical Development and Current Issues.” Bilingual Research Journal 27 (1): 1-24. doi:1 0.1080/15235882.2003.10162589.

Petrovic, J. E. 2005. "The Conservative Restoration and Neoliberal Defenses of Bilingual Education.” Language Policy 4 (4): 395-416. doi:10.1007/ s10993-005-2888-y.

Plyler, V. D. (1982). 457 U.S. 202, 102 S. Ct. 2382, 72 L. Ed. $2 d 786$.

READ Act (2012). "House Bill 12-1238: Reading to Ensure Academic Development Act.” Accessed November 28, 2016. http://www.cde.state.co.us/sites/default/ files/documents/cdesped/download/pdf/sdm2012oct coloradoreadact.pdf

Reichard, R. "Why We Say 'Latinx': Trans \& Gender Non-Conforming People Explain”. Latina. Accessed Aug.29, 2015. http://www.latina.com/lifestyle/ our-issues/why-we-say-latinx-transgender-non-conforming-people-explain

Rogers, R., E. Malancharuvil-Berkes, M. Mosley, D. Hui, and G. O. G. Joseph. 2005. "Critical Discourse Analysis in Education: A Review of the Literature." Review of Educational Research 75 (3): 365-416. doi:10.3102/00346543075003365.

Rolstad, K., K. Mahoney, and G. V. Glass. 2005. "The Big Picture: A Meta-Analysis of Program Effectiveness Research on English Language Learners.” Educational Policy 19 (4): 572-594. doi:10.1177/0895904805278067.

Ruiz, Richard. 1984. "Orientations in Language Planning." Nabe Journal 8 (2): 1534. doi:10.1080/08855072.1984.10668464.

San Miguel, G. 2004. Contested Policy: The Rise and Fall of Federal Bilingual Education in the United States, 1960-2001. Vol. 1. Denton: University of North Texas Press.

Santa Ana, O. 2002. Brown Tide Rising: Metaphors of Latinos in Contemporary American Public Discourse. Austin, TX: University of Texas Press.

Schildkraut, D. J. 2003. "American Identity and Attitudes toward Official-English Policies.” Political Psychology 24 (3): 469-499. doi:10.1111/pops.2003.24. issue-3.

Science Core Group. 2015. ELL Rules. Written public comment at the meeting of the Colorado Board of Education. Denver, CO. http://www.boarddocs.com/co/ cde/Board.nsf/files/gVBME758BA81/\$file/3.12.15\%20ELL\%20Rules.pdf 
Senate Bill. No. 1174. 2014. English Language Education. https://leginfo. legislature.ca.gov/faces/billNavClient.xhtml?bill id=201320140SB1174

Shohamy, E. G. 2006. Language Policy: Hidden Agendas and New Approaches. New York \& Abingdon: Routledge.

Smith, R. M. 1997. Civic Ideals: Conflicting Visions of Citizenship in US History. New Haven, CT: Yale University Press.

Solano-Flores, G. 2008. "Who Is Given Tests in What Language by Whom, When, and Where? the Need for Probabilistic Views of Language in the Testing of English Language Learners." Educational Researcher 37 (4): 189-199. doi:10.3102/0013189X08319569.

Sólorzano, D. G., O. Villalpando, and L. Oseguera. 2005. "Educational Inequities and Latina/O Undergraduate Students in the United States: A Critical Race Analysis of Their Educational Progress." Journal of Hispanic Higher Education 4 (3): 272-294. doi:10.1177/1538192705276550.

Solórzano, R. W. 2008. "High Stakes Testing: Issues, Implications, and Remedies for English Language Learners.” Review of Educational Research 78 (2): 26o329. doi:10.3102/0034654308317845.

Sung, K. K. 2017. “'Accentuate the Positive; Eliminate the Negative': Hegemonic Interest Convergence, Racialization of Latino Poverty, and the 1968 Bilingual Education Act." Peabody Journal of Education 92 (3): 302-321. doi:10.1080/016 1956X.2017.1324657.

Suthers, J. W. (August 12, 2014). Formal Opinion of John W. Suthers, Attorney General, No. 14-02. State of Colorado Department of Law, Office of the Attorney General. Accessed September 25, 2016. http://coag.gov/sites/default/ files/contentuploads/ago/agopinions/john-w-suthers/2014/no-14-02.pdf

Umansky, I. M., and S. F. Reardon. 2014. "Reclassification Patterns among Latino English Learner Students in Bilingual, Dual Immersion, and English Immersion Classrooms." American Educational Research Journal 51 (5): 879912. doi:10.3102/ooo2831214545110.

Urciuoli, B. 1996. Exposing Prejudice: Puerto Rican Experiences of Language, Race, and Class. Boulder, CO: Westview Press.

Valdés, F. 1997a. "Foreword: Under Construction. LatCrit Consciousness, Community, and Theory." California Law Review 85 (5): 1087-1142. doi:10.2307/3481057.

Valdés, G. 1997b. "Dual-Language Immersion Programs: A Cautionary Note Concerning the Education of Language-Minority Students." Harvard Educational Review 67 (3): 391-430. doi:10.17763/ haer.67.3.n5q175qp86120948.

Valentino, R. A., and S. F. Reardon. 2015. "Effectiveness of Four Instructional Programs Designed to Serve English Learners Variation by Ethnicity and Initial English Proficiency." Educational Evaluation and Policy Analysis 37 (4): 612637. doi:10.3102/0162373715573310.

Viesca, K. M. 2013. "Linguicism and Racism in Massachusetts Education Policy." Education Policy Analysis Archives 21 (52). Accessed September 25, 2016. doi:10.14507/epaa.v21n52.2013. 
Viesca, K. M., and Poza, L. E. Forthcoming. "Colorado's READ Act: A Case Study in Policy Advocacy against Monolingual Normativity.” In Language and Social Justice in Practice, edited by Netta Avineri, Robin Conley Riner, Laura R. Graham, and Jonathan Rosa. New York: Routledge.

“Westminster School Dist. Of Orange County V. Mendez." (9th Cir. 1947). 161 F.2d 774 .

Wiley, T. G. 2000. "Continuity and Change in the Function of Language Ideologies in the United States." In Ideology, Politics, and Language Policies: Focus on English, edited by T. Ricento, 67-85. Amsterdam, NE and Philadelphia, PA: John Benjamins.

Wiley, T. G. 2013. "A Brief History and Assessment of Language Rights in the United States." In Language Policies in Education: Critical Issues, edited by J. W. Tollefson, 61-9o. 2nd ed. London, England: Routledge.

Wiley, T. G. 2014. "Diversity, Super-Diversity, and Monolingual Language Ideology in the United States: Tolerance or Intolerance?” Review of Research in Education 38 (1): 1-32. doi:10.3102/oo91732X13511047.

Wiley, Terrence G. 2007. "Accessing Language Rights in Education: A Brief History of the U.S. Context". In Bilingual Education: An Introductory Reader, edited by Ofelia Garcia and Colin Baker, 89-107. Clevedon: Multilingual Matters LTD.

Yosso, T., O. Villalpando, D. Delgado Bernal, and D. G. Solórzano; (2001). "Critical Race Theory in Chicana/O Education. (2001).” Proceedings from the National Association for Chicana and Chicano Studies Annual Conference. Accessed July 20, 2018. http://scholarworks.sjsu.edu/naccs/2001/Proceedings/9

Zentella, A. C. 1997. Growing up Bilingual: Puerto Rican Children in New York. Malden, MA: Blackwell Publishing. 